\title{
PENGARUH NEO-REVIVALIS ISLAM TERHADAP SEKULERISME DI PALESTINA
}

\section{Said Abdullah Syahab}

UIN Raden Fatah Palembang

Email: duniacomputerok@yahoo.co.id

\begin{abstract}
This article discusses the thrill intersection of neo-revilaimse with secularism in the Islamic world, especially in the Middle East. Cases taken is the gait of the Muslim Brotherhood through the wings organization Hamas in Palestine in blocking the growth of secularism. Awakening Muslims the world accompanied by the development of neo-revivalist Islam that aspires to restore Islam without eliminating nationalism against the state. Hamas has gained support and trust of the Palestinian people. Secularism it resulted Muslims are marginalized politically, economically, and culturally. This article found that movement was a reaction to Islamic neorevivalis Western hegemony and a new awareness among Muslims against the teachings of Islam that has long been missing from the implanted western secularism.

Artikel ini membahas serunya persinggungan neo-revilaimse dengan sekulerisme dalam Dunia Islam khususnya di Timur Tengah. Kasus yang diambil adalah kiprah Ikhwanul Muslimin melalui organisasi sayapnya yakni Hamas di Palestina dalam menghadang pertumbuhan sekulerisme. Kebangkitan Umat Islam dunia diiringi dengan berkembangnya Neo-revivalis Islam yang bercita-cita mengembalikan Islam tanpa menghilangkan nasionalisme terhadap negara. Hamas telah mendapatkan dukungan dan kepercayaan rakyat Palestina. Sekulerisme justru mengakibatkan umat Islam termarjinalkan bidang politik, ekonomi, dan budaya. Artikel ini menemukan bahwa gerakan neorevivalis Islam merupakan reaksi atas hegemoni Barat dan kesadaran baru umat Islam terhadap ajaran Islam yang telah lama hilang akibat sekulerisme yang ditanamkan Barat.
\end{abstract}

Keywords: Ikhwanul Muslimin, Neorevivalis Islam, Modernisme, Fundamentalisme, Sekulerisme 


\section{Pendahuluan}

Neorevivalis Islam merupakan gerakan yang ingin mengembalikan tatanan dunia dengan kekhalifahan Islam yang diyakini merupakan tatanan yang diajarkan dalam ajaran Islam. ${ }^{1}$ Penerapan nizam al-Islami (tatanan Islam), bakimiyyat Allab (kedaulatan Tuhan) dan syariat secara global merupakan idealisme tertinggi yang ingin dicapai. Tatanan tersebut menggantikan tatanan dunia kontemporer yang berorientasi kapitalis dan nilai-nilai sekuler Barat. ${ }^{2}$ Umat Islam memerlukan institusi untuk mencapai idealisme tata dunia Islami. ${ }^{3}$

Khilafah merupakan "negara" yang di dalamnya tegak syariat dan kedaulatan Tuhan berkuasa di dalamnya ${ }^{4}$. Kekhilafahan adalah kepemimpinan tunggal bagi muslim untuk menegakkan syariat dan mengemban dakwah Islam ke seluruh dunia. Khilafah diperlukan untuk membangun tatanan Islami. ${ }^{5}$ Pendirian khilafah mengatasi kondisi keterpurukan muslim, mewujudkan keadilan, kehormatan, kesejahteraan dan segala kebaikan bagi manusia pada umumnya, umat Islam khususnya ${ }^{6}$. Khilafah menjadikan umat Islam sebagai pihak dominan pembawa kebaikan, keadilan, serta stabilitas. Pendirian khilafah mampu mengembalikan umat Islam kepada puncak kejayaan sebagaimana dalam sejarah peradaban Islam. An Nabhani menyatakan bahwa Daulah Khilafah bukanlah khayalan pemimpi, sebab terbukti telah memenuhi pentas sejarah selama 13 abad. Ini adalah kenyataan. Daulah Khilafah merupakan kenyataan di masa lalu dan tidak lama

1John L Esposito, Ancaman Islam: Mitos atau Realitas (Jakarta: Mizan. 1999). Bassam Tibi, Ancaman Fundamentalisme: Rajutan Islam Politik danKekacanan Dunia Baru (Jogjakarta: Tiara Wacana Yogya, 2000), 34.

2Sayyid Quthb, Petunjuk Sepanjang Jalan (Jakarta: Serambi, 1980), 53.

${ }^{3}$ An-Nabhani, Benturan Peradaban Sebuah Keniscayaan (Jakarta: Hizbut Tahrir Indonesia. 2002), 43.

${ }^{4}$ Sayyid Quthb, Petunjuk Sepanjang Jalan (Jakarta: Serambi, 1980), 89.

${ }^{5}$ Khalid Novianto, "Pemetaan Gerakan Islam Transnasional di Indonesia." Reform Review Journal, (2007), 189. Al-Farag dalam John L. Esposito, Ancaman Islam: Mitos atau Realitas (Jakarta: Mizan, 1999). Lihat pula Mawdudi dalam Cox dan Marks (2003) mengatakan: "The ultimate goal of Islam is the state of the world. The goal of Islam is to rule the entire world and submit all of mankind to the faith of Islam. Any nation or power in this world that tries to get in the way of that goal, Islam will fight and destroy them."

${ }^{6}$ An-Nabhani, Benturan Peradaban Sebuab Keniscayaan (Jakarta: Hizbut Tahrir Indonesia.2002), 99. 
lagi akan menjadi kenyataan masa modern walau dalam bentuk yang berbeda. ${ }^{7}$

\section{Neo-Revivalisme Islam}

Gelombang neo-revivalisme Islam ${ }^{8}$ menjadi sebuah fenomena sejak dekade 1970-an di Timur Tengah. Namun, secara historis, realitas fenomena ini telah ada sejak dekade terbentuknya Ikhwanul Muslimin pada akhir 1920-an. Kebangkitan Islam sejak dekade tersebut ditandai maraknya perjuangan pengaplikasian ajaran Islam secara menyeluruh dalam kehidupan budaya, hubungan sosial, persoalan-persoalan ekonomi dan kehidupan politik. Terciptanya Islam kaffah (utuh) dalam berbagai sektor kehidupan menjadi tujuan utama gelombang neo-revivalisme ini. Kebangkitan Islam dilatarbelangi kesadaran umat islsm untuk berperilaku religius sesuai dengan norma-norma Islami. Berbeda dengan revivalisme Islam pada abad ke-18 yang hanya menekankan sisi legalitas penerapan syariat, neo-revivalisme berorientasi mewujudkan syariat Islam sebagai sebuah ideologi politik.

Bentuk kebangkitan Islam tidak lagi terbatas pada tingginya kesadaran beribadah dan menjalankan perintah dan meninggalkan laranganNya saja namun juga menempatkan Islam sebagai sebuah ideologi dalam rangka mewujudkan bakimiyyat Allah (kedaulatan Tuhan) melalui persatuan umat Islam secara global.Kemunculan awal neo-revivalisme tahap awal sejalan dengan keberadaan kolonialisme di Timur Tengah. Kelahiran fenomena neo-revivalisme linear dengan realitas dunia Islam yang pada umumnya mengalami perubahan sosiokultural pasca-Perang Dunia I (1913), keruntuhan imperium Turki Ustmani (1924), serta kolonialisme negara-negara Barat. Pada masa itu, negara-negara kolonial membagi-bagi kawasan Timur Tengah

${ }^{7}$ Dalam sejarahnya sekitar 1300 tahun, kepimpinan Islam (khilafah) berhasil menaungi dunia Islam. Khilafah mampu menyatukan umat Islam di seluruh dunia. Khilafah juga menerapkan syariat kaffah sehingga terwujud kerahmatan yang dijanjikan bagi seluruh alam. Lihat: An-Nabhani, Benturan Peradaban Sebuah Keniscayaan (Jakarta: Hizbut Tahrir Indonesia, 2002), 100.

${ }^{8}$ Neorevivalis berprinsip bahwa kedaulatan sepenuhnya milik Tuhan. Kalimat syahadat (laa ilaa ha illallah, mubammadar rasulullab) bermakna tiada pemerintahan, tiada kekuasaan, dan tiada sistem kecuali kekuasaan dan sistem Tuhan. Tiada kedaulatan kecuali kedaulatan Tuhan.

${ }^{9}$ Bassam Tibi, Ancaman Fundamentalisme: Rajutan Islam Politik dan Kekacauan Dunia Baru (Jogjakarta: Tiara Wacana Yogya, 2000), 250.

TAJDID vol. XV, No. 2, Juli - Desember $2016 \mid 3$ 
menjadi berbagai wilayah untuk kepentingan penjajahan. Peperangan antarnegara kolonial juga kerap terjadi terjadi di Timur Tengah. ${ }^{10}$

Pelopor gerakan neorevivalis pertama adalah Ikhwanul Muslimin yang berdiri pada 1928. Awal berdirinya gerakan ikhwanul muslimin sering dianggap sebagai gerakan radikal seperti pada gerakan Islam lainnya. Bangkitnya gerakan Neo-revivalisme Islam dianggap sebagai bangkitnya kelompok muslim fanatik yang bereaksi keras melawan the great Satan, yaitu Amerika Serikat dan negara-negara Barat lainnya. Tren perlawanan terhadap Barat tidak lagi terbatas pada masalah mengenai kultur kehidupan melainkan juga menyangkut konfrontasi ideologi politik dan militer. ${ }^{11}$

Di kalangan sekuler sering membenturkan neorevivalis dengan kelompok-kelompok Islam denominasi tradisionalis, nasionalis, maupun moderat ${ }^{12}$. Dan menganggap bahwa cita-cita neorevivalis akan menimbulkan kontroversi karena keinginan kelompok neorevivalis menerapkan syariat Islam mendiskrimasi nonmuslim sebagai warga kelas dua sehingga neo-revivalisme Islam dianggap membahayakan tatanan dunia ${ }^{13}$. Disamping gerakan ikhwanul muslimin ini dianggap berbahaya karena akan menghilangkan nasionalisme dalam negara-negara mayoritas muslim. Ikhwanul Muslimin bercita-cita untuk mengembalikan kejayaan Islam, membangkitkan situasi perekonomian umat Islam yang secara umum semakin terpuruk, keprihatinan terhadap organisasi internasional yang didominasi oleh kepentingan negara-negara Barat. Disamping itu dominasi yang mirip kolonialisme abad ke-19 oleh negara Barat atas negara-negara muslim yang sedang berkembang dan negara miskin. Upaya mengembalikan Ikhwanul muslimin harus berhadapan dengan sekulerisme yang telah menguat dinegara-negara muslim.

\section{Sekulerisme vs Ikhwanul Muslimin}

Sejarah sekuler sudah ada sejak datangnya masa The Dark Age of Christ (masa kegelapan Kristen). Marthin Luther dan John Calvin

${ }^{10}$ Nuim Hidayat, Imperialisme Baru (Jakarta: Gema Insani Press, 2009), 90.

${ }^{11}$ Gerakan Islam seperti Ikhwanul Muslimin menyakini kewajiban iqamah ad-dawlah al-Islamiyah (pendirian negara Islam) sebagai sarana menjalankan syariat Islam.

${ }^{12}$ Khalid Novianto, "Pemetaan Gerakan Islam Transnasional di Indonesia." Reform Review Journal, (2007), 63.

${ }^{13}$ Bassam Tibi, Ancaman Fundamentalisme: Rajutan Islam Politik dan Kekacauan Dunia Baru (Jogjakarta: Tiara Wacana Yogya, 2000), 90.

4 | TAJDID vol. XVI, No. 1, Januari - Juli 2017 
adalah perintis bibit awal yang secara tidak langsung menimbulkan adanya seruan untuk menjadi sekuler. Pada masa kegelapan Kristen, Agamawan menjadi penguasa Negara yang Corrupt. Marthin menemukan berbagai macam kesalahan-kesalahan yang dilakukan oleh gereja mengenai Bibble, inkuisi gereja terhadap umat manusia seperti Nicolaus Copernicus dan Gallileo Galilei sebagai seorang ilmuan yang dianggap menentang kekuatan gereja. A Guillaume menyatakan bahwa "Tak ada satu masalahpun bertentangan dengan ilmu yang didalamnya ada agama, kecuali yang benar di pihak ilmu dan yang salah di pihak sekutu agama".Sekularisme lahir di tengah carut marut peradaban barat yang tenggelam dalam kebodohan. ${ }^{14}$

Sekulerisme berpandangan bahwa Islam hanya sebuah ajaran yang mengatur hubungan antara manusia dengan Tuhannya, tidak ada hubungannya dengan urusan ketatanegaraan atau yang populer dengan faham sekulerisme(saeculum). Sekularisme dalam bahasa arabnya di kenal dengan istilah al-'Imaniyyah didefinisikan sebagai faham yang memisahkan antara agama (religion) dengan negara (state). ${ }^{15}$ Sekularime bermula pada zaman pencerahan abad ke-17 Masehi sampai dengan abad ke-19 Masehi yang bersamaan dengan keruntuhan keyakinan keagamaan kristen oleh arus kebangkitan akal rasional, empirisme dan kemajuan sains. ${ }^{16}$ Abdul Wahab Al-Masiri membagi sekularisme pada dua macam; pertama, sekularisme parsial ('almaniyah jusiyyah) dan sekularisme totalistik ('almaniyah syamilah), ${ }^{17}$

${ }^{14}$ Wamy, Gerakan Keagamaan dan Pemikiran (Akar Ideologis dan Penyebarannya) (Jakarta: Al-I'tishom Cahaya Umat, 2002), 285. Lihat pula: Nurcholish Madjid, Tradisi Islam, Peran dan Fungsinya dalam Pembangunan di Indonesia (Jakarta: Paramadina, 1997), 90. Abdul Wahab Al-Masiri membagi sekularisme pada dua macam: pertama, sekularisme parsial (ilmaniyah juriyyah) dan sekularisme totalistik ('ilmaniyah syamilab). Sekularisme parsial (sekularisme) adalahsebagai paham yang memisahkan antara negara dan agama, sedangkan sekularisme totalistikadalah melepaskan kehidupan dari nilai-nilai humanisme, moral dan agama. Abdul Wahab al-Masiri, al-ílmaniyah al-Shamilah wa al-ilmaniyah al-Juz'iyah, (Kairo: Dār al-Shurq, t.th), 6. Atau lihat juga: Sayyid Muhammad Naquib al-Attas, Islam dan Sekularisme (Bandung: Penerbit Pustaka, 1981), 42.

${ }^{15}$ Bahtiar Effendy, Agama Publik dan Privat: Pengalaman Islam Indonesia (Jakarta: PPIM UIN Jakarta dan UIN Press, 2009), 15.

${ }^{16}$ Sayyid Muhammad Naquib al-Attas, Islam dan Sekularisme (Bandung: Penerbit Pustaka, 1981). 90.

${ }^{17}$ Sekularisme pada dua macam; pertama, sekularisme parsial ('almaniyah juriyyah) dan sekularisme totalistik ('almaniyah syamilab). sekularisme parsial (atau lebih dikenal dengan istilah fashl al-din 'an al-daulab) tidak lebih hanya sekedar membedakan mana yang menjadi urusan negara yang notabena bersifat duniawi

TAJDID vol. XV, No. 2, Juli - Desember $2016 \mid 5$ 
sedangkan Sayyid Muhammad Naquib Al-Attas membedakan antara arti sekularisme dan sekularisasi. ${ }^{18}$ Menurut Al-Attas, sekularisasi (sekularisme totalistik) maupun sekularisme (sekularisme parsial) sama sekali tidak sesuai dengan ajaran Islam. Karena keduanya mengandung nilai-nilai yang tidak sesuai dengan Islam. Islam sebagai sebuah agama, peradaban dan bahkan kehidupan itu sendiri tidak bisa disandingkan atau malahan diganti dengan ideologi lain seperti sekulerisme ${ }^{19}$

Dengan demikian sekuler merupakan pemahaman yang menginginkan pemisahan antara agama dengan negara, agama berada diluar negara dan merupakan urusan pribadi warga negara serta tidak ada hubungannnya dengan ketatenegaraan.Sekularisme juga memandang bahwa simbol-simbol agama harus dihilangkan karena hal ini dapat memicu terjadinya pertentangan atau perpecahan. ${ }^{20}$ Faham ini banyak mengadopsi nilai-nilai Budaya Barat (Westernisasi), ${ }^{21}$ seperti yang dilakukan faham Kemalis (Kemalism) yang berhasil mendirikan Republik Turki (1923 M)dan membebaskan segala institusi politik dari kekuasaan agama. 2223

Sebagian besar pemimpin rezim negara Arab berasal dari kelompok nasionalis-sekular atau sosialis-komunis dan sebagian besar penguasa Timur Tengah pascakemerdekaan merupakan alumni

dan urusan agama yang bersifat ukhrawi. Abdul Wahab Al-Masiri, Al-'Almaniyah Al-Syamilah wa Al-'Almaniyah Al-jur'iyah (Kairo: Daru Al-Syurq, t.th), 6.

18Sayyid Muhammad Naquib al-Attas, Islam dan Sekularisme (Bandung: Penerbit Pustaka, 1981), 20.

${ }^{19}$ Sayyid Muhammad Naquib al-Attas, Islam dan Sekularisme (Bandung: Penerbit Pustaka, 1981), 42.

${ }^{20}$ Peter L. Berger, (ed), The Desecularization of the World: Resurgent Religion and World Politics (Washington: Wm. B. Eerdmans Publishing, 1999), 87-88.

${ }^{21}$ Sekulerisme berasal dari faham kristen sebagaimana berbunyi dalam kitab sucinya "Geeft dan den Keizer wat des Keizers is, en Gode wat Gods is" yang artinya adalah berikanlah kepada kaisar yang merupakan milik kaisar dan berikan kepada tuhan yang merupakan milik tuhan (Marcus 12 : 17). Mark Jurgensmeyer, The New Cold War: Religious Nationalism Confort the Secular State, (teri) Noorhadi Menentang Negara sekuler: Kebangkitan Global Nasionalisme Religius (Bandung: Mizan, t.th), 45.

${ }^{22}$ Harun Nasution, Pembaharuan dalam Islam (Jakarta: Bulan Bintang, 1992), 154.

${ }^{23}$ Bahtiar Effendy, Agama Publik dan Privat: Pengalaman Islam Indonesia (Jakarta: PPIM UIN Jakarta dan UIN Press, 2009), 15. Lihat pula: Sayyid Muhammad Naquib al-Attas, Islam dan Sekularisme (Bandung: Penerbit Pustaka, 1981), 90.

6 | TAJDID Vol. XVI, No. 1, Januari - Juli 2017 
pendidikan Barat yang berpaham ideologi sekuler. Reformasi yang dilakukan negara-negara kolonial Barat maupun oleh rezim pemerintahan negara-negara Timur Tengah menyebabkan dunia Islam secara gradual berintegrasi pada sistem Barat yang sekuler. ${ }^{24}$

Sekulerisme di negara-negara muslim khususnya di timur tengah yang mengikuti sistem barat dalam pembangunannya juga telah gagal menghasilkan kemajuan-kemajuan di bidang ekonomi. Usaha-usaha pembangunan dengan sistem kapitaliseme gagal menghasilkan kemajuan ekonomi. Dalam satu dekade hingga tahun 1980-an, ratarata tingkat kemiskinan di negara-negara mayoritas muslim meningkat dari 28 persen hingga 45 persen. Kondisi ini membuat konsep ekonomi alternatif yang dimiliki oleh ajaran Islam (konsep ekonomi Islam) yang dibawa gerakan Islam khususnya Ikhwanul Muslimin. Selain ketimpangan ekonomi juga ditandai oleh konflik geopolitik baru antara negara-negara muslim dengan negara-negara Barat. Kasus paling menonjol terjadi di Bosnia-Herzegovina. Selama masa konflik di negara itu, terjadi pembersihan etnis muslim oleh kaum Ortodoks Serbia. Peristiwa ini menyadarkan umat Islam khususnya rakyat di Palestina bahwa bahwa mereka tiak dapat mempercayakan keamanan umat Islam terhadap umat non muslim. ${ }^{25}$ Kesadaran ini seiring ketidakadilan dan penzholiman terhadap gerakan Islam dalam perpolitikan yang dialami FIS di Aljazair dan Refah di Turki . Gerakan Islam harus berhadapan dengan Amerika Serikat dan sekutunya setelah berakhirnya Perang Dingin Amerika Serikat ingin menciptakan "Tatanan Dunia Baru”. ${ }^{26}$

Sekuler di TimurTengah khuusnya di Palestina telah berhadapan dengan gerakan Islam Ikhwanul muslimin yang memiliki idealisme yang ingin diwujudkan dalam gerakan politiknya dan sering dituduh sebagai kelompok fundamentalis. Ikhwanul Muslimin berupaya menegakkan agama menjadi ideologi politik yang mencakup sistem ekonomi, budaya, dan sosial. Dan menolak produk-produk sekulerisme yang cenderung mendukung westernisasi kecuali yang memberikan kemaslahatan. Gerakan Islam kontemporer ini

${ }^{24}$ Asep Romli, Demonologi Islam: Upaya Barat Membasmi Kekuatan Islam (Jakarta: Gema Insani Press, 2000), 34. Atau lihat pula: Basam Tibi, Ancaman Fundamentalisme: Rajutan Islam Politik dan Kekacauan Dunia Baru (Jogjakarta: Tiara Wacana Yogya, 2000), 90.

${ }^{25}$ Asep Romli, Demonologi Islam: Upaya Barat Membasmi Kekuatan Islam. (Jakarta: Gema Insani Press, 2000), 98.

26Nuim Hidayat, Imperialisme Baru (Jakarta: Gema Insani Press, 2009), 28.

$$
\text { TAJDID Vol. XV, No. 2, Juli - Desember } 2016 \mid 7
$$


menegaskan bahwa agama dapat diterpakan secara kaffah. Tuntutan penerapan syariat berlawanan dengan konsep sistem Barat oleh karenanya gerakan Islam ini sering dibenturkan dengan kalangan tradisionalis. Gerakan pembaharuan melakukan larangan terhadap alkohol, bunga pinjaman, perjudian, musik, perbauran antara pria dan wanita, serta larangan penampilan unsur-unsur seksualitas dalam publik. Aspek yang dibenturkan Ikhwanul muslimin dengan kalangan tradisionalis dikarenakan kalangan tradsional menerima aspek budaya lokal dalam menerapkan syariat, sedangkan Ikhwanul Muslimin mengaplikasikan syariat secara puritan dan menyeluruh. Perbedaanperbedaan ini yang diajadikan sebagai alat untuk memisahkan dan menjauhkan serta memecah belah antara Ikhwanul muslimin dengan kelompok Islam tradisional oleh kaum sekuler.

Pendirian negara Israel di wilayah Palestina juga memicu krisis berkepanjangan bagi Timur Tengah. Negara kolonial Inggris memiliki kepentingan besar untuk mendukung berdirinya negara Israel di Palestina. Deklarasi Balfour yang kemudian diadopsi oleh League of Nations (LBB) memberikan mandat resmi kepada Inggris untuk mendirikan Israel. Beberapa peperangan pernah terjadi antara negaranegara Arab dengan Israel. Namun, dalam empat perang Arab-Israel yang terjadi pada 1948, 1956, 1967, dan 1973 hampir semuanya berakhir dengan kekalahan negara-negara Arab. Pada era pascakolonial, negara-negara Islam telah mengalami perubahan revolusioner. Perubahan tersebut meliputi land reform, industrialisasi, penegasan supremasi nasionalisme, pengadopsian sosialisme dan sebagian kapitalisme Barat, pemberlakuan kontrol negara terhadap institusi-institusi masyarakat serta beberapa aspek sekulerisme ${ }^{27}$

Neorevivalis, dunia internasional sekarang berada di suasana jabiliyah yang serupa dengan suasana jabiliyah pada zaman kedatangan Islam 15 abad lalu. Konsep hidup manusia sekarang adalah hasil ciptaan jabiliyah. ${ }^{28 S e r a n g a n}$ pemikiran dalam hal propaganda peradaban Barat seperti liberalisme, demokrasi, kapitalisme, pluralisme, civil society, insitusi negara, HAM, hak-hak perempuan,

${ }^{27}$ Shireen T. Hunter, Politik Kebangkitan Islam: Keragaman dan Kesatuan. (Jogjakarta: Tiara Wacana Yogya, 2001), 98.

${ }^{28}$ Sayyid Quthb, Petunjuk Sepanjang Jalan (Jakarta: Serambi, 1980), 100.

8 | TAJDID vol. XVI, No. 1, Januari - Juli 2017 
ikatan patriotisme, dialog antar agama, dan sebagainya dirasakan sebagai benturan dalam kehidupan sehari-hari. ${ }^{29}$

Kaum neorevivalis memandang globalisasi adalah proses yang menjadikan kapitalisme sebagai ideologi universal yang harus dianut oleh semua bangsa secara sukarela atau terpaksa, serta pemaksaan peradaban Barat dan nilai-nilainya kepada dunia. Globalisasi adalah proses menjadikan sistem kapitalisme Amerika sebagai sistem dunia. Globalisasi merupakan proses memudarnya tapal batas antarnegara secara ekonomi, budaya, ideologi, maupun sosial, serta kondisi dunia global menjadi bagaikan kampung kecil di hadapan kapitalisme. Inti globalisasi adalah imperialisme baru.Neo-revivalisme Islam memiliki misi menegakkan tatanan Tuhan menggantikan tatanan sekularmodern Barat. Neo-revivalisme Islam muncul sebagai gerakan ideologi sosial-politik. Neorevivalis Islam menjadi gerakan ideologis menyatukan entitas lokal dalam satu tatanan berdasar ideologi agama sesuai visi absolut tatanan Tuhan. Permulaan neo-revivalisme Islam dapat ditelusuri pada dekade 1930-an hingga 1960-an. Dalam era ini, fenomena neo-revivalisme Islam paralel dengan proses perjuangan dekolonialisasi ${ }^{30}$. Pada awal dekade tersebut, berkembang dua organisasi Islam, yaitu Ikhwanul Muslimin pimpinan Hasan Al Banna dan Jamaat Islami pimpinan Abu a'la al-Mawdudi. Hasan Al Banna dan Quthb dengan organisasinya masing-masing memiliki pengaruh signifikan.

Ikhwanul Muslimin meyakini bahwa Islam tidak sekadar agama melainkan juga merupakan mabda' (ideologi). Ideologi tersebut tidak hanya menjadi alternatif ketiga sesudah kapitalisme Barat ataupun Marxisme, tetapi merupakan ideologi yang harus diwujudkan. Islam sebagai satu-satunya "way of life". Gerakan neorevivalis mendapat sambutan dari berbagai kalangan terutama kalangan kelas menengah, terutama pelajar, mahasiswa, pekerja, pedagang, kaum professional dan ulama. Perjuangan kaum neorevivalis beriringan dengan agenda negara-negara Timur Tengah untuk mendapatkan kemerdekaan dari negara-negara kolonial. 3132

${ }^{29}$ An-Nabhani, Benturan Peradaban Sebuah Keniscayaan (Jakarta: Hizbut Tahrir Indonesia, 2002), 98.

30Peter R. Demand, Islam vs Islamism: The Dilemma of the Muslim World (New York: Praeger Publishers, 2006), 60.

${ }^{31}$ John L. Esposito, Ancaman Islam: Mitos atau Realitas (Jakarta: Mizan, 1999), 97.

TAJDID vol. XV, No. 2, Juli - Desember $2016 \mid 9$ 
Perkembangan pesat gerakan neorevivalis Islam terjadi pada akhir 1950-an hingga 1970-an. Perang Arab-Israel dan perang di Lebanon, memicu protes terhadap sistem kehidupan sosial dan kompetensi pemerintah. Pemerintahan di negara-negara muslim terpuruk dengan kondisi perpolitikan dalam dan luar negeri. Negaranegara Timur Tengah tidak mampu menjaga kedaulatan negara. Realitas tersebut memunculkan kekecewaan masyarakat muslim, khususnya di negara-negara Timur Tengah. Di kawasan itu, terdapat resistensi terhadap hegemoni Barat dan keinginan untuk kembali kepada identitas autentik. 33

Dalam pemahaman Ikhwanul Musimin bahwa hal -hal yang baik dar budaya barat dan keilmuan dapat diserap selama tidak bertentangan dengan konsep Islam. Islam dipandang sebagai jalan tengah dari dua ideologi ekstrim, komunisme dan kapitalisme. Islam merupakan kekuatan ketiga yang mandiri di antara kedua kutub tersebut. Tidak ada yang dapat menggantikan Islam dari dunia Islam dan Timur Tengah. Islam sebagai ideologi politik dan ajaran agama merupakan satu-satunya solusi atas permasalahan umat dalam kehidupan modern. Kegagalan penerapan kapitalisme, liberalisme, dan komunisme membuat wacana ideologi Islam menjadi populer.

Di Mesir, Syiria dan Tunisia, gerakan-gerakan Islam tampil sebagai reaksi dan perlawanan terhadap nasionalisme sekuler. Neorevivalis beranggapan bahwa Islam telah dilemahkan dalam negara sekuler. Karena itu, gerakan-gerakan Islam eksis untuk memperjuangkan pendirian negara Islam sebagai syarat bagi berlakunya syariat Islam. Neo-revivalisme Islam berkembang pesat pada dekade 1950-an dan 1960-an. Neo-revivalisme Islam sebagai satu gerakan sosial-politik berupaya memapankan sistem kehidupa Islam puritan di tengah hegemoni Barat. kemunculan neo-revivalisme Islam dipicu krisis-krisis dalam kolonialisasi dan kesadaran umat Islam dunia terhadap imperialisme Barat terhadap dunia Islam. Pimpinan Ikhwanul Muslimin yakni Hasan al Banna telah menjadi salah satu inspirator bagi kesadaran umat Islam akan jati dirinya serta keterpurukan umat Islam sebagai akibat dominasi Barat pada dekade

${ }^{32}$ Daniel Pipes, In the Name of God (New Jersey: Transaction Publishers, 2003), 98.

${ }^{33}$ Terdapat empat alternatif masyarakat Arab terhadap hegemoni Barat, yaitu: keaslian Arab, keaslian nasional, Arab-Islam, dan Islam Puritan. Silahkan lihat: Imdadun Rahmat, Arus Baru Islam Radikal: Transmisi Revivalisme Islam Timur Tengah ke Indonesia (Jakarta: Erlangga, 2005), 90.

10 | TAJDID Vol. XVI, No. 1, Januari - Juli 2017 
kontemporer. Hasan al banna memberikan ide, konsepsi, visi dan misi identik dengan prinsip-prinsip Ikhwaunul Muslimin. Revivalisme Islam kontemporer tidak dapat dilepaskan dari krisis-krisis di dunia Islam yang dipacu oleh dominasi Barat.

Gema kebangkitan Islam diiringi dengan kebangkitan gerakan neorevivalis kontemporer juga berorientasi antitesis terhadap pertumbuhan ekonomi dan nilai-nilai kapitalis. Selain itu, identitas Barat mendominasi dalam pop culture, life style, dan sistem pemikiran. Akibatnya, aktivis neorevivalis memandang adanya ghaw zul fikri (perang pemikiran) neorevivalis berorientasi pada revolusi perubahan proses globalisasi berjalan searah sebagaimana pada tahap awal dalam proses tersebut. Neorevivalis Islam bercita-cita mengembalikan era keemasan Islam pada masa imperium sebagai kehidupan idealis umat Islam. Khazanah keilmuan Islam yang kaya dari era imperium menjadi indikator bagi gerakan-gerakan neorevivalis untuk mengunggulkan faktor historis dalam arah perjuangan kelompok mereka.

Islam Timur Tengah juga diposisikan sebagai Islam relatif lebih murni dengan pengikut puritan. Praktek ajaran Islam Timur Tengah menjadi acuan bagi Islam di wilayah lain. Sentra-sentra keilmuan dan institusi pendidikan Islam terletak di kawasan Timur Tengah. Berbagai keunggulan yang dimiliki Islam Timur Tengah menjadikan Islam di wilyah ini sebagai sumber rujukan. Dinamika keagamaan, intelektualitas, politik, kebudayaan, dan sejarah gerakan sosial politik Timur Tengah dengan mudah diadaptasi oleh umat Islam di kawasan lain. Karena itu, ideologi neorevivalis Islam Timur Tengah mudah menyebar ke kawasan lain.

\section{Ikhwanul Muslimin di Palestina}

Palestina belum mendapatkan pengakuan secara penuh oleh masyarakat dunia sebagai negara merdeka dan menghadapi ancaman dan penjajahan Israel ${ }^{34}$ namun Palestina memiliki otoritas pemerintahan yang mewakili aspirasi rakyatnya. Salah satu kelompok yang berpengaruh dalam kehidupan sosial-politik Palestina adalah

${ }^{34}$ Berdirinya Israel tidak bisa dipisahkan dari gerakan Zionisme yang didukung negara-negara imperialis Barat. Sejak mendeklarasikan gerakan Zionisme (1996), Theodor Herzl mulai berkerjasama dengan negara-negara imperialis seperti Amerika Serikat, Inggris, Perancis dan Rusia mewujudkan citacitanya mendirikan negara Israel di bumi Palestina. http://hizbuttahrir.or.id/2008/05/16/60-tahun-derita-palestina-sampai-kapan/

TAJDID Vol. XV, No. 2, Juli - Desember 2016 | 11 
Gerakan Hamas, ${ }^{35}$ yang sedang berhadapan dengan Israel dalam mempertahanan negaranya yang secara bertahap diambil Israel.

Berdirinya Israel tidak bisa dipisahkan dari gerakan Zionisme yang didukung negara-negara imperialis Barat. Sejak mendeklarasikan gerakan Zionisme (1996), Theodor Herzl mulai berkerjasama dengan negara-negara imperialis seperti Amerika Serikat, Inggris, Perancis dan Rusia mewujudkan cita-citanya mendirikan negara Israel di bumi Palestina. 36

HAMAS telah merupakan gerakan sosial dan politik yang menjadikan Islam sebagai ideology dan mengikis pengaruh sekulerisme di Palestina. Pada dasarnya lahirnya gerakan sosial HAMAS adalah suatu upaya untuk melakukan perubahan dengan menajadikan Islam sebagai visi kehidupan bernegara.Hamas sebagai Gerakan Islam pada dasarnya ingin melakukan perubahan sosial rakyat Palestina. Secara historis prsoses berdirinya gerakan Hamas, ada dua faktor utama yang menyebabkan Hamas berdiri.Pertama, tumbuhnya al-tayyār al-Islämī aliran Islam yang didorong oleh intifada al-Aqșā, di mana pada waktu itu, di setiap kampus dan institusi pendidikan di Palestina terdapat kelompok-kelompok pemuda Palestina yang berani turun ke jalan mengatasnamakan Islam dan rakyat Palestina. Kedua, kebrutalan pasukan militer Israel terhadap rakyat sipil Palestina, menyebabkan mereka terdorong untuk bergabung dalam sebuah gerakan yang bisa melawan kebrutalan Israel.Disinilah Gerakan Hamas mendapatkan momentumnya. ${ }^{37}$

\footnotetext{
حركة المقاومة (حماس) dalam bahasa Arab merupakan singkatan dari Gerakan Perlawanan Islam di Palestina. Hamas merupakan gerakan keagamaan yang berjuang untuk mencapai kemerdekaan rakyat Palestina. Hamas didirikan sebagai organisasi perlawanan terhadap penjajahan Israel pada akhir tahun 1987 M. Khālid Khalì Mạ̣mūd Zuaib. al-'Alāqah Baina Harakah alMuqāwamah al-Islāmiyyah (Hamās) wa al-Urdun (Yordaniah: Jāmi'ah Khalil, 2010), 2.

${ }^{36}$ Keberadaan negara Israel di jantung Timur Tengah tentu saja akan bermanfaat bagi negara-negara Imperialis. Negara Israel bisa dijadikan alat untuk berbagai kepentingan politik. Pernyataan Ezer Weizman mencerminkan hal itu: "Seandainya tidak ada Israel, maka tidak ada pihak yang mampu membantu kepentingan kerajaan Inggris." http://hizbut-tahrir.or.id/2008/05/16/60tahun-derita-palestina-sampai-kapan/

${ }^{37}$ Khālid Khāil Maḥmūd Zuaib. al-'Alāqah Baina Harakah alMuqāwamah al-Islämiyyah (Hamās) wa al-Urdun (Yordaniah: Jāmi'ah Khalil, 2010),2-5.
}

12 | TAJDID Vol. XVI, No. 1, Januari - Juli 2017 
Tokoh pendiri Gerakan Hamas yang paling berpengaruh adalah Syekh Ahmad Yasin. ${ }^{38}$ Tepatnya pada tanggal 9 Desember 1987, Syekh Yasin mengumpulkan beberapa tokoh di rumahnya untuk membicarakan rencana pendirian gerakan Islam untuk memperjuangkan rakyat Palestina. Hadir dalam pertemuan itu diantaranya, Ṣalāh Shahadah dari Bait Ḥānūn, 'Isa al-Nasshār dari Kota Rafah, Ibrāhìm al-Yāzūrì dari Gazza, Abdul Azīz al-Rantīisi dai Khān Yünus dan tokoh-tokoh penting lainnya. Pada saat itulah Gerakan Hamas dibentuk atas kesepakatan tokoh-tokoh yang berkumpul di kediaman Syekh Yasin.Dan disepakati juga dalam pertemuan tersebut bahwa masing-masing tokoh yang hadir menjadi pemimpin Hamas di wilayahnya masing-masing. ${ }^{39}$

Dalam percaturan gerakan sosial dan politik, kelompok Hamas disebut Islamisme "al-Islämiyyūn". ${ }^{40}$ Begitu pula Al-Jihād al-Islämì (Jihad) mulai dikenal luas sejak tahun 1986 meskipun ia memiliki akar sejarah hingga tahun 1971 di tangan Syekh Abdullah Darwish yang menyeru masyarakat untuk kembali pada Islam dan meyakini Islam sebagai agama sekaligus konsep negara. Namun, Jihad sejak tahun 1990 pecah menjadi tiga kelompok, yaitu Jihad Palestina, Jihad Baitul Maqdis, dan Jihad Brigade al-Aqsha. Tujuan dan strategi kelompok ini tidak jauh dari kelompok Hamas di atas, mendirikan negara Islam dan menggunakan jihad (perlawanan fisik) dalam menghadapi musuh daripada perundingan.

Hamas adalah Organisasi yang sangat terkenal namun hakikatnya sedikit diketahui oleh khalayak. Akar dari Gerakan Hamas berakar dari kelompok Ikhwanul Muslimin di Mesir. Yang menjadikan Hamas sebagai upaya perlawanan secara terbuka terhadap Israel dan

${ }^{38}$ Nama lengkapnya adalah Ahmad Ismail Yasin yang berprofesi sebagai guru di Madrasah, khatib sekaligus imam di Masjid Gaza. Silahkan lihat: Ahmad Mansur, Al-Syaikh Ahmad Yăsin Syāhidun 'ala al-'Așr(t.tt: t.p., th), 25.

${ }^{39}$ Zaki Shihāb. Hamās min al-Dākhil, al-Qișsah ghair al-Marwiyyah 'an al-Muqāwimīn wa al-Shuhadā wa al-Jawāsīs (Beirūt: al-Dār al-'Arabiyyah li al-'Ulüm), 45-46.

${ }^{40}$ Hamas merupakan kelompok Islam yang menjadikan Allah sebagai tumpuan perjuangannya, Islam sebagai manhaj kehidupannya, dan berjuang untuk menegakkan panji-panji Allah wst.di tanah Palestina. Dengan demikian, maka pantaslah Hamas digolongkan al-Islamiyyun kelompok Islamisme di Palestina. Khālid Khāil Mạ̣mūd Zuaib. al-'Alāqah Baina Harakah alMuqāwamah al-Islāmiyyah (Hamās) wa al-Urdun (Yordaniah: Jāmi'ah Khalil, 2010), 6.

TAJDID Vol. XV, No. 2, Juli - Desember 2016 | 13 
memberikan sumbangsih sosial yang besar bagi rakyat Palestina, seperti membangun sekolah, klinik, rumah sakit untuk membantu penderitaan rakyat Palestina. ${ }^{41}$

Hubungan antara Hamas dan Ikhwanul Muslimin juga dipertegas oleh Iyād al-Bargūthì. Ia mengatakan bahwa pada fase awal pendiriannya, Gerakan Hamas merupakan gerakan sayap dari Ikhwanul Muslimin. Bisa dilihat dari basis perjuangan dan ideologi Hamas, sama sekali tidak berbeda dengan perjuangan dan ideologi Ikwanul Muslimin. Sebagai contoh, ketika berbicara mengenai ideologi keIslaman yang diperjuangkan, Hamas mengambil syiar Ikhwanul Muslim yaitu: Allah adalah tujuan kami, Rasul adalah pembimbing kami, al-Qur'an adalah dustür(undang-undang) kami, jihad adalah jalan kami, dan mati dalam jihad di jalan Allah adalah keinginan kami yang paling tinggi. ${ }^{42}$

Hamas berpusat di Jalur Gaza. Dalam kehidupan sosial politik Palestina, Hamas banyak membantu korban perang dengan Israel dan kadangkala terlibat dalam perlawanan melawan Israel. Selama intifada berlangsung, Hamas telah memberikan konstribusi besar dalam peningkatan kondisi sosial dan keagamaan masyarakat, peningkatan infrastruktur di bidang pendidikan di Jalur Gaza dan West Bank. Garakan Hamas sangat dikenal dengan gerakan amal untuk kemanusiaan. Bagi masyarakan Palestina di Jalur Gaza dan West Bank, Hamas merupakan Gerakan Sosial penyelamat karena ideologi dan solidaritasnya yang tinggi terhadap bangsa Palestina. ${ }^{43}$

Penjajahan Israel membuat HAMAS harus berjuang untuk merebut kembali tanah Palestina yang saat ini dikuasai Israel, jika diawal perjuangannya HAMAS memiliki persenjataan yang sangat sederhana namun kini telah mengalami kemajuan dalam persenjataan yang pesat. Berikut adalah peta wilayah Palestian setelah direbut Israel yang hanya meliputi Jalur Gaza dan Tepi Barat: ${ }^{44}$ Bagi Hamas, Islam

${ }^{41}$ Matthew Levitt, Hamas: Politics, Charity, and Terrorism in The Service of Jihad (London: Yale University Press, 2006), 3.

42‘'yād al-Bargūthì.al-Islām al-Siyāsì fì Filistịn (al-Qudsi: Markaz alQuds li al-I'lām wa al-Ittiṣālāt, 2000), 92.

${ }^{43}$ Kasjim Salenda, Terorisme dan Jihad dalam Perspektif Hukum Islam (t.tt: t.p., t.th), 189.

${ }^{44}$ Emanuel Schäublin, Role and Governance of Islamic Charitable Institutions: The West Bank Zakat Committees (1977-2009) in the Local Context (Geneva: The Centre on Conflict, Development and Peace-building, 2009), 1.

14 | TAJDID vol. XVI, No. 1, Januari - Juli 2017 
adalah asas utama pergerakannya dan nilai-nilai yang ada di dalamnya merupakan pegangan hidup yang dijadikan rujukan bagai para prajuritnya dalam bertindak. Tuduhan radikal selalu diberikan kepada HAMAS namun dalam perkembangannya hingga akhirnya dunia di sadarkan akan kegigihan pejuang HAMAS melawan penjajahan di bumi palestina dan diterima serta mendapatkan dukungannya HAMAS oleh Turki dan Arab Saudi. 45
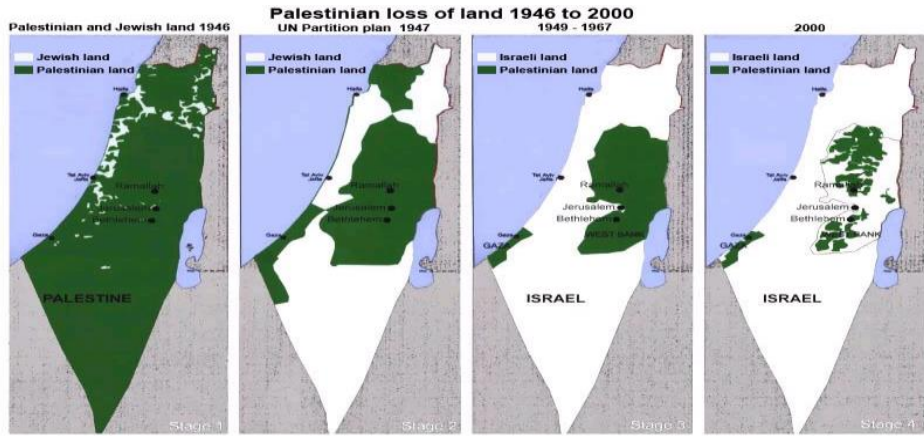

Sumber : http://www.stopthewall.org/news/maps.shtml

Hamas beseberangan dengan Palestinian League Organization (PLO) beraliran sekuler yang pimpinan Yasser Arafat yang tunduk terhadap kepentingan Barat dan Israel di Palestina. Hamas melakukan perlawanan terhadap Israel walau dengan persenjataan yang seadanya dan melakukan gerakan bawah tanah dan serta serangan bom bunuh diri ke tentara Israel serta mengirim rudal kewilayah Israel. Hamas yang memiliki komitment menolak perundingan dengan Israel sering harus berhadapan dengan PLO yang didukung Israel. Seiring meninggalnya Yasir Arafat,PLO semakin kurang mendapatkan dan dukungan masyarakat Palestina dan sebaliknya Hamas yang berpartisipasi aktif di arena politik memperoleh keberhasilan dengan memenangkan pemilihan umum di Gaza, Qalqilya dan Nablus, Hamas berhasil mendominasi anggota di parlemen Palestina dengan meraih 76 kursi dari 132 pada Januari 2006.46

${ }^{45}$ Hamas sebenarnya memiliki akar historis mulai dari didirikannya cabang organisasi Ikhwanul Muslimin di Gaza tahun 1946. Lihat: Jean-Pierre Filiu, "The Origins of Hamas: Militant Legacy or Israeli Tool?" Journal of Palestine Studies, Vol. 41, No. 3 (Spring 2012), 54-70. t.th), 201.

${ }^{46}$ Kasjim Salenda, Terorisme dan Jihad dalam Perspektif Hukum Islam (t.tt: tp., 


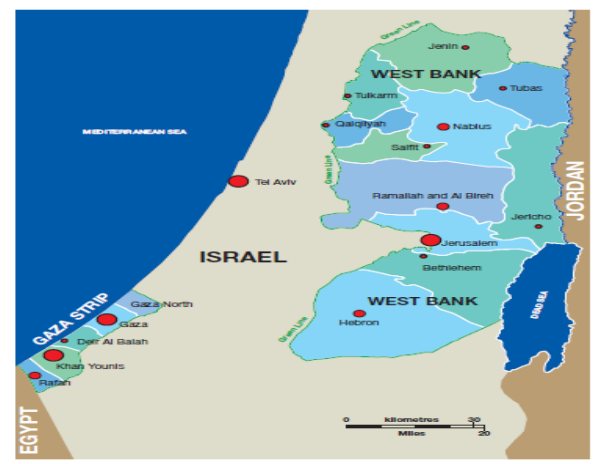

Sumber : Emanuel Schäublin.Role and Governance of Islamic Charitable Institutions: The West Bank ZakatCommittees (1977-2009)in the Local Context (Geneva: The Centre on Conflict, Development and Peace-building, 2009), 1.

Sejak Hamas memutuskan ikut Pemilu dengan membentuk partai politik di Palestina tahun 2006, Hamas telah menjadi kekuatan politik yang secara cepat mendapatkan dukungan mayoritas rakyat Palestina. ${ }^{47}$ Pemilu yang diadakan dengan keikut-sertaan Hamas yang dinilai oleh banyak kalangan sebagai pemilu yang jujur dan bersih. ${ }^{48}$ Kemenangan Hamas yang sangat demokratis tidak secara langsung menimbulkan perubahan iklim politik Palestina yang lebih Islamis mengingat Hamas memiliki cita-cita yang sama dengan gerakan Islam Ikhwanul Muslimin.Keberhasilan Hamas untuk bisa mengemban aspirasi rakyat yang diperoleh melalui proses pemilihan yang demokratis, dan Setelah Hamas telah mendapatkan dukungan dan kepercayaan rakyat Palestina maka tugas berat diemban gerakan Islam modern ini terutama menyelasaikan masalah-masalah politik dan kemasyarakatan rakya Palestina. Dan masalah yang paling mendesak adalah menghadapi kezaliman Israel tehadap rakyat Palestina. Berbagai negara duniapun telah mengeluarkan dukungan kemerdekaan Palestina. Kehadiran Hamas yang sejalan dengan

${ }^{47}$ Menachem Klein, "Hamas in Power”, Middle East Journal, Vol. 61, No. 3 (Summer, 2007), 442-459. Menachem mengemukakan bahwa deklarasi pimpinan Hamas menjadi faksi politik telah menjadi perdebatan yang sangat menarik dalam atmosfer politik Timur-Tengah. Dalam tulisannya ini, ia juga menyayangkan inkonsistensi Hamas mengenai sikapnya terhadap perdamaian Israel. Hamas menegaskan bahwa Israel adalah musuh selamanya. Di sisi lain Hamas juga tetap membuka pintu perundingan damai dengan Israel.

${ }^{48}$ Mariam 'Itani. al-Sirā' al-Sultăt baina Fatạ wa Hamās, fì Idārat alSultah al-Filistiniyyah (Beirūt: Markaz al-Zaitūnah li al-Dirāsāt wa alIstishärät, 2008), 5.

16 | TAJDID Vol. XVI, No. 1, Januari - Juli 2017 
konsep Ikhwanul Muslimin dan bagian gerakan Neorevivalis tidak menghilangkan nasionalisme dari pejuang Hamas untuk mendapatkan kemerdekaan dan tidak rela tanah negaranya direbut Israel.

\section{Kesimpulan}

Berbagai gerakan neorevivalis Islam merupakan reaksi atas hegemoni Barat dan kesadaran baru umat Islam terhadap ajaran Islam yang telah lama hilang akibat sekulerisme yang ditanamkan barat. pergerakan neorevivalis Islam di hampir seluruh belahan dunia akan berhadapan dengan Barat dan kaum sekulerisme nasionalis yang mendukung hegemoni Barat dalam dunia Islam. Sekulerisme justru menimbulkan umat Islam termarjinalkan bidang politik, ekonomi, dan budaya. Kesadaran dan kebangkitan Umat Islam di dunia khususnya Pejuang Palestina yang dikomandoi Hamas yang merupakan bagian dari gerakan Islam Ikhwanul Muslimin untuk berhadapan dengan tentara Israel dan membebaskan negaranya dari penjajahan Israel

\section{Daftar Pustaka}

Al-Banna, Hasan. Risalah Pergerakan Ikhwanul Muslimin 1. Solo: Era Intermedia, 2005.

-----, Risalah Pergerakan Ikhwanul Muslimin 2. Solo: Era Intermedia, 2005.

Al-Hakayamah, Muhammad Khalil. Al-Qaeda Membongkar Intelijen Amerika. Jakarta: Islamika, 2008.

An-Nabhani. Benturan Peradaban Sebuah Keniscayaan. Jakarta: Hizbut Tahrir Indonesia, 2002.

-----, Daulab Islam. Jakarta: HTI Press, 2009.

Baskara, Nando. Gerilyawan-Gerilyawan Militan Islam. Jakarta: Buku Kita, 2009.

Bubalo, Anthony. Joining the Caravan: Midde East, Islamism, and Indonesia. New South Wales: Lowy Institute for International Polic, 2005.

Cox, Caroline dan John Marks. The West, Islam, \& Islamism: Is Islam Compatible with Democracy. London: Civitas. 1999.

Demand, Peter R. Islam vs Islamism: The Dilemma of the Muslim World. New York: Praeger Publishers, 2006.

Esposito, John L. Islam dan Pembaharuan: Ensiklopedi Masalah-Masalah. Jakarta: RajaGrafindo, 1993.

TAJDID Vol. XV, No. 2, Juli - Desember 2016 | 17 
-----, Ancaman Islam: Mitos atau Realitas. Jakarta: Mizan, 1999.

Emanuel Schäublin. Role and Governance of Islamic Charitable Institutions: The West Bank Zakat Committees (1977-2009) in the Local Context. Geneva: The Centre on Conflict, Development and Peacebuilding, 2009.

Hidayat, Nuim. Imperialisme Baru. Jakarta: Gema Insani Press, 2009.

Hunter, Shireen T. Politik Kebangkitan Islam: Keragaman dan Kesatuan. Jogjakarta: Tiara Wacana Yogya, 2001.

Huntington, Samuel P. Benturan Antar Peradaban. Jogjakarta: Qalam, 2001.

Lib For All Foundation, Ilusi Negara Islam: Ekspansi Gerakan Islam Transnasional. Jakarta: Desantara Utama Media, 2009.

Mariam 'Itani. al-Sirā' al-Sultāt baina Fatạ wa Hamās, fí Idārat alSultah al-Filistiniyyah. Beirūt: Markaz al-Zaitūnah li alDirāsāt wa al-Istishārāt, 2008.

Matthew, Levitt. Hamas: Politics, Charity, and Terrorism in the service of jihad. London: Yale University Press, 2006.

Mirsel, Robert. Teori Pergerakan Sosial. Jogjakarta: Resist Book, 2004.

Pipes, Daniel, In the Name of God. New Jersey: Transaction Publishers, 2003.

Quthb, Sayyid. Petunjuk Sepanjang Jalan. Jakarta: Serambi, 1980.

Rahmat, Imdadun, Arus Baru Islam Radikal: Transmisi Revivalisme Islam Timur Tengah ke Indonesia. Jakarta: Erlangga, 2005.

Romli, Asep. Demonologi Islam: Upaya Barat Membasmi Kekuatan Islam. Jakarta: Gema Insani Press, 2000.

Roy, Oliver. Gagalnya Islam Politik. Jakarta: Serambi Lilmu Semesta, 1996.

Tibi, Bassam. Ancaman Fundamentalisme: Rajutan Islam Politik dan Kekacauan Dunia Baru. Jogjakarta: Tiara Wacana Yogya, 2000.

------, Political Islam: World Politics and Europe. New York: Roudledge, 2008.

Romli, Asep. Demonologi Islam: Upaya Barat Membasmi Kekuatan Islam. Jakarta: Gema Insani Press, 2000.

Novianto, Khalid. Pemetaan Gerakan Islam Transnasional di Indonesia. Reform Review Journal, 1 (1), 2007.

18 | TAJDID vol. XVI, No. 1, Januari - Juli 2017 